\title{
Brazil
}

\section{Automatic Patent Term Extensions Ruled Unconstitutional in Brazil: Better Late Than Never?}

\author{
Mário André Machado Cabral
}

(C) Max Planck Institute for Innovation and Competition, Munich 2022

\section{Introduction}

The Brazilian Federal Supreme Court (STF) recently handed down one of its most important decisions ever. ${ }^{1}$ The STF ruled that Art. 40, sole paragraph, of Law No. 9,279/1996 (Industrial Property Act, hereinafter "IPA") is unconstitutional. This provision established a rule of automatic extension of patent terms. The standard term for invention patents is 20 years from the application filing date at the national industrial property authority (Instituto Nacional de Propriedade Industrial, hereinafter INPI) (Art. 40, caput $^{2}$ IPA). But if the examination by the patent office takes longer than 10 years, invention patents will be valid for at least 10 years from the date on which the patent was granted. ${ }^{3}$ In other words, beyond the protection provided following the patent publication, the patent holder enjoys an additional 10 -year protection. This usually leads to exclusivity terms of more than 20 years. Moreover, as the patent grant by the office is not predictable, it is not known when the patent will expire.

25 years after the IPA went into effect, the Court considered the sole paragraph inconsistent with several articles of the Brazilian Constitution of 1988. Among

\footnotetext{
1 For a translation of an edited summary of the STF's decision No. 672/2020 - Unconstitutionality of Patent Extensions, into English, see this issue of IIC at https://doi.org/10.1007/s40319-021-01144-9.

2 In Brazilian legislation "caput" ("head" in Latin) is the main section of an Article when it contains subsections or paragraphs. The "caput" contains the primary statement.

3 "Article 40. The invention patent will be valid for a period of 20 (twenty) years and a utility model patent for a period of 15 (fifteen) years from the filing date. Sole paragraph. The term of validity will not be less than 10 (ten) years for an invention patent and 7 (seven) years for a utility model patent, counted from the grant date, except in case the INPI is prevented from proceeding with the examination of the application, due to a proven pending judicial decision or due to force majeure" (author's translation).
}

M. A. M. Cabral (ه)

PhD in Economic Law (University of São Paulo); S. Fellow (Engelberg Center on Innovation Law \& Policy), New York University, New York, USA

e-mail: marioandremc@gmail.com 
them, the constitutional Article that assures "temporary privilege" to the authors of industrial inventions (Art. 5, XXIX) should be highlighted. According to the STF, the term extension was opposed to the constitutional idea that patent exclusivity should be temporary. ${ }^{4}$

\section{Procedural Aspects and Covid-19}

The claim ("Direct Action of Unconstitutionality" - ADI No. 5,529) was made in 2016 by then Prosecutor General Rodrigo Janot, and comprised a significant number of amici curiae - most of them business associations potentially affected by the decision. The case has gained traction since the beginning of the Covid-19 crisis onwards.

On 7 April 2021, the Rapporteur of the collegiate, Justice Dias Toffoli, issued a preliminary injunction to suspend the effects of Art. 40, sole paragraph, IPA, on pharmaceutical patents and medical equipment. Among the arguments presented by the Justice was the pandemic crisis. The longer the sole paragraph provision remained in force, the greater the damage resulting from an undue and unconstitutional exclusivity. In a crisis such as that of Covid-19, the need to manage scarce healthcare resources was clear. Extending the patent term would imply scarcer resources in the face of monopoly prices for medicines and other patented health-related products and processes. ${ }^{5}$

Justice Toffoli's provisional decision ended up becoming definitive, as it was reaffirmed by him at the final judgment on 6 May 2021 and followed by a 9-2 majority vote. From the decision, it is important to underline not only the unconstitutionality of the referred Article in itself, but also the modulation of decision effects. ${ }^{6}$ Justice Toffoli ruled that the effects of the unconstitutionality decision would not be retroactive so as to include patents already granted based on Art. 40, sole paragraph, IPA. However, this parameter would accommodate two exceptions. First, lawsuits discussing the sole paragraph would be affected by the STF's decision. Second, patents already granted based on Art. 40, sole paragraph, involving pharmaceutical products and processes and health-related equipment would also be affected by the unconstitutionality decision. Regarding the latter, the patent holder would enjoy the standard protection according to Art. 40, caput (20 years for invention patents and 15 years for utility model patents, starting from the patent application filing date and without any sort of extension).

\footnotetext{
4 See all the documents concerning the case at STF's official website: Supremo Tribunal Federal. ADI No. 5,529. Rap. Justice Dias Toffoli. Date of judgment 6 May 2021. Available at: http://portal.stf.jus.br/ processos/detalhe.asp?incidente $=$.

5 See on the costs of term extensions to the Brazilian National Health System: Julia Paranhos, Eduardo Mercadante and Lia Hasenclever "O custo da extensão da vigência de patentes de medicamentos para o Sistema Único de Saúde”. Cad. Saúde Pública, vol. 36, No. 11, 2020. pp. 1-13. Available at: http://pt. scielosp.org.

6 See on the modulation of effects in the case: Flávio Jardim et al. "O prazo das patentes e a modulação dos efeitos". Jota, 11 May 2021. Available at: https://www.jota.info/opiniao-e-analise/artigos/o-prazodas-patentes-e-a-modulacao-dos-efeitos-11052021.
} 
More relevant than the outcome of the case are the arguments addressed by the Court in order to assess - 25 years after the IPA entered into force - the constitutionality of such an important rule.

\section{Legal Anachronism and International Isolation}

Article 40, sole paragraph, IPA, grants an automatic patent term extension under the following terms. According to the Art. 40, caput, the standard patent term is 20 years for invention patents and 15 years for utility model patents, from the application filing date at the INPI. Nonetheless, Art. 40, sole paragraph, assures to the patent holder exclusivity of at least 10 years (for invention patents) or 7 years (for utility model patents), from the date on which the patent was granted.

A clear example of the situation in Brazil is an invention patent mentioned in Justice Toffoli's opinion: the drug Vonau Flash. The patent application filing occurred in 2005, but the patent was only granted by the INPI in 2018. Instead of an expiration ending in 2025, according to the standard rule of Art. 40, caput, the patent would still be valid until 2028 because of the exceptional rule of Art. 40, sole paragraph. That is, the society would have to bear at least an additional three years of exclusivity before generics would be allowed to enter the market.

At least two aspects - in addition to the specific unconstitutionalities discussed below - suggest the sole paragraph's anachronism.

First, there is already a rule protecting the holder's rights even before the patent is granted - Art. 44 IPA. $^{7}$ This Article provides the holder with the right to seek damages concerning unauthorized patent use between the filing publication and the patent grant. ${ }^{8}$ Such a tool may be (and actually is) used by patent holders in order to inhibit competitors. It is reasonable to assert that, in practice, the exclusivity begins prior to the patent grant. ${ }^{9}$ Article 40, sole paragraph, works as an automatic widening of patent exclusivity. When Art. 44 is added to Art. 40, sole paragraph, the result allows for a disproportionate private benefit to the patent holder, on the one hand, and barriers to entry for competitors alongside with negative exclusivity consequences for the public, on the other hand. ${ }^{10}$

\footnotetext{
7 "Article 44. The patent holder is guaranteed the right to obtain compensation for the improper exploitation of its object, including in relation to the exploitation occurring between the application publication date and the patent grant date" (author's translation).

8 See on the lawsuits for damages caused by industrial property violations in Brazil: Denis Borges Barbosa "Valor indenizável das violações da propriedade intelectual". Available at: https://www.dbba. com.br/wp-content/uploads/valor_indenizavel.pdf.

9 See Grupo Direito e Pobreza - USP “A inconstitucionalidade do artigo 40, parágrafo único, da Lei de Propriedade Industrial sob uma perspectiva comparada”. São Paulo, 2020. pp. 17-18. Available at: https://papers.ssrn.com/sol3/papers.cfm?abstract_id=3745372.

10 See Denis Borges Barbosa "A inexplicável política pública por trás do parágrafo único do art. 40 da Lei de Propriedade Industrial”. pp. 43-44. Available at: http://a-inexplicvel-poltica-pblica-por-trs-dopargrafo-nico-do-art-40-pargrafo-nico-do-cpi.96-agosto-de-2013.pdf.dbba.com.br. On the inhibition of competitors' entry prior to the patent grant (specifically in the pharmaceutical sector in Brazil), see Gabriela Costa Chaves et al. "Medicamentos em situação de exclusividade financiados pelo Ministério da Saúde: análise da situação patentária e das compras públicas". Rio de Janeiro: Fiocruz, ENSP, 2018.
} 
Second, international experience indicates that the possibilities of patent term extension are exceptional and not automatic. Because of Art. 40, sole paragraph, the effective patent term in Brazil is significant and greater with respect to the compared countries. According to the Law and Poverty Research Group (University of São Paulo), the average patent term in Brazil is 24.305 years. This is highest term among the BRICS countries (Brazil, Russia, India, China and South Africa), Latin American countries, as well as the six countries with the highest average terms (Brazil, Switzerland, Italy, UK, US and Sweden). ${ }^{11}$ Justice Toffoli has stressed that Brazil is the only developing country in such top- 6 list, indicating a "disadvantage in the international scenario regarding access to medicines and the enforcement of health as a right". 12

It is important to remark that patent term extension is not TRIPS-required. Article 40, caput, IPA, already addresses the standard TRIPS protection (20 years for invention patents and 15 years for utility model patents from the filing date). Article 40, sole paragraph is thus a "TRIPS-plus" measure, which brings us to the conclusion that the unconstitutionality decision does not lead us to any sort of noncompliance with international law commitments. ${ }^{13}$

In addition to the right to health - which in Brazil is a constitutional right and is, according to the STF, negatively affected by Art. 40, sole paragraph - other constitutional provisions were considered to be undermined by the automatic patent term extension. The next two sections discuss such issues.

\footnotetext{
Footnote 10 continued

p. 128. Available at: http://naf.ensp.fiocruz.br/sites/default/files/relatorio_projeto_monopolio_v_final_ divulgacao_18_12_2018.pdf; Ana Claudia Dias Oliveira "Estratégias para adiar o acesso aos medicamentos no Brasil" in: Pedro Villardi et al. (eds.). Prêmio GTPI Jacques Bouchara de produção acadêmica voltada para o ativismo. Rio de Janeiro: Associação Brasileira Interdisciplinar de AIDS, 2015. pp. 68-69. Available at: https://issuu.com/gtpi/docs/premio_gtpi_web.

${ }^{11}$ See Grupo Direito e Pobreza - USP "A inconstitucionalidade do artigo 40, parágrafo único, da Lei de Propriedade Industrial sob uma perspectiva comparada”. São Paulo, 2020. pp. 35-43. Available at: https://papers.ssrn.com/sol3/papers.cfm?abstract_id=3745372.

12 See Justice Toffoli's opinion. ADI No. 5,529, 7 April 2021. p. 46. Available at: http://portal.stf.jus.br/ processos/detalhe.asp?incidente $=$. For a recent criticism on the US patent term extension system, see Ethan Lin "Recommendations for statutory reform of the patent term extension system to increase public accountability and fight soaring drug prices". Engelberg Center on Innovation Law \& Policy, NYU School of Law, March 2021. Available at: https://www.law.nyu.edu/sites/default/files/recommendationsfor-statutor-reform-of-the-patent-term-extension-system-2021-03.pdf.

${ }^{13}$ See Vitor Henrique Pinto Ido "The role of courts in implementing TRIPS flexibilities: Brazil Supreme Court rules automatic patent term extensions unconstitutional". South Centre Policy Brief, No. 94, June 2021. pp. 1-3. Available at: https://www.southcentre.int/policy-brief-94-june-2021/. Inappropriately arguing that unconstitutionality ruling is not consistent with international law, see Maristela Basso "Revogação do parágrafo único do art. 40 da LPI viola o direito internacional". Jota, 28 April 2021. Available at: https://www.jota.info/opiniao-e-analise/artigos/revogacao-art-40-lpi-direito-internacionalpropriedade-intelectual-28042021.
} 


\section{Temporary Privilege and Predictability}

The Brazilian constitutional provision dealing specifically with industrial property rights is Art. 5, XXIX. ${ }^{14}$ Taking this Article into consideration, four aspects may be pointed out. ${ }^{15}$

First, the Brazilian Constitution prescribes the mandatory drafting of an industrial property act. If, when the Constitution was enacted in 1988, there was no act specifically designed to protect industrial creators, the Brazilian Parliament should discuss a bill with such aim. Actually, there was an industrial property act at that time (Act No. 5,772/1971), which remained in effect until 1996, when the IPA was issued. ${ }^{16}$

Second, by recognizing that a privilege must be granted to the creators of industrial inventions, the Constitution legitimizes patent exclusivity, although "free competition" is a principle also enshrined in the Constitution (Art. 170, IV).

Third, by affirming that the privilege is temporary, the Brazilian Constitution does not allow an ad eternum exclusivity. If exclusivity did not meet duration limits, other constitutionally relevant principles - such as free competition, for example would be mitigated.

Fourth, the privilege should be instrumental, as it is not an end in itself. In other words, patent exclusivity serves broader goals, namely, the "social interest and the technology and economic development of the country" (Art. 5, XXIX, Brazilian Constitution).

The temporary nature of the privilege is the middle way between an ad eternum privilege, on the one hand, and the lack of any privileges to the industrial creator (i.e. free access to inventions), on the other hand. Such equilibrium is desired so that the incentives for innovation - allegedly arising from patent exclusivity - do not overcome important constitutional values, such as the social interest, free competition and consumer protection.

Article 40, sole paragraph, IPA, disrupts the balance by relativizing the temporary nature of industrial property protection. It establishes a rule of indeterminate patent duration. If the minimum terms of Art. 40, sole paragraph, only begin when the patent is granted, but the grant only takes place at an uncertain time in the future, a circumstance of unpredictability arises because it is not known when the exclusivity ends.

\footnotetext{
14 "Article 5, XXIX. The law shall grant creators of industrial inventions temporary privilege for their use, as well as protection for industrial creations, brand ownership, company names and other distinctive signs, in view of the social interest and the technological and economic development of the country" (author's translation).

${ }^{15}$ For a constitutional analysis of intellectual property legal framework in Brazil, see Denis Borges Barbosa "Bases constitucionais da propriedade intelectual". Available at: https://www.dbba.com.br/wpcontent/uploads/propriedade13.pdf.

16 Act No. 5,772 / 1971 did not provide patent protection for chemical products or pharmaceutical and nutritional processes and products. The changes in Brazilian intellectual property framework in the 1990s were a result of TRIPS and international pressures. See e.g. Carolyn Deere "The implementation game: The TRIPS agreement and global politics of intellectual property reforms in developing countries". New York: Oxford University, 2009. pp. 8-9 and 40.
} 
The temporary quality of the industrial property privilege aims at providing predictability. Disregarding the temporary attribute of patent protection results in harms for: (1) legal certainty (Art. 5, XXXVI, Brazilian Constitution); (2) the principle of a reasonable duration of the proceedings (Art. 5, LXXVIII, Brazilian Constitution); and (3) efficiency in the public administration (Art. 37, Brazilian Constitution). The STF's ruling has properly addressed such concerns.

In the opposite direction, one may argue that the INPI's backlog is actually what is inconsistent with legal certainty, the principle of reasonable duration of the proceedings, and efficiency in the public administration. The STF has acknowledged that the backlog is inefficient $;{ }^{17}$ however, based on a report from the Federal Court of Auditors, the STF found that it is not unusual that patent applicants seek to delay the analysis of applications by the INPI through procedural means. Thus, the backlog would be partly due to the applicants' own procedural behavior, once they know in advance that the delay will lead to term extension backed by Art. 40, sole paragraph. Therefore, the sole paragraph would foster this delaying behavior, adding to concerns on the duration of the proceedings and administrative efficiency. ${ }^{18}$

\section{5 “Excessive Advantage" and Market Power}

The STF has ruled that exclusivity of more than 20 years (for invention patents) or 15 years (for utility model patents) represents an "excessive advantage" to the patent holder ${ }^{19}$. Such terms (20 and 15 years) are the appropriate standard, according to international parameters and Art. 40, caput, IPA. Three aspects deserve to be pointed out.

First, such an advantage is not reasonable because, as mentioned, between the application filing publication and the patent grant, the IPA assures to the holder the right to seek damages concerning unauthorized patent use (Art. 44). Therefore, even if the INPI takes a long time to grant the patent, the holder may inhibit competitors and enforce a de facto exclusivity even before the grant. What arises is that the patent holder, in practice, enjoys protection beginning with the patent application filing publication. Article 40, sole paragraph, IPA, is not directed to guarantee a term of exclusivity that was not enjoyed before due to the patent authority's backlog. Actually, the sole paragraph's aim is to improperly enlarge an exclusivity that, in practice, was already being enjoyed by the holder. In other words, the IPA, through Art. 44, already offers protection to the patent holder, regardless of the INPI's backlog. ${ }^{20}$ Thus, the sole paragraph is an excess, an unreasonable privilege,

\footnotetext{
17 That is why the STF ruled that the INPI should undertake a number of measures to address the backlog problem, including hiring additional staff. See Justice Toffoli's opinion. ADI No. 5,529, 7 April 2021. pp. 34 and 80-81. Available at: http://portal.stf.jus.br/processos/detalhe.asp?incidente=.

18 See Justice Toffoli's opinion. ADI No. 5,529, 7 April 2021, p. 69. Available at: http://portal.stf.jus.br/ processos/detalhe.asp?incidente $=$.

${ }^{19}$ See Justice Toffoli's opinion. ADI No. 5,529, 7 April 2021, p. 69. Available at: http://portal.stf.jus.br/ processos/detalhe.asp?incidente $=$.
} 
not imposed by the TRIPS Agreement and is inconsistent with international experience and the Brazilian Constitution.

Second, Art. 40, sole paragraph, holds the potential to increase the patent holder's market power. Patent exclusivity, not to mention the mitigation of short-run static competition, is constitutionally admitted because it is assumed that it fosters technological innovation, which may be taken as an expression of another type of competition, a dynamic one. ${ }^{21}$ The fact is that patent exclusivity, even in the shortrun, may result in a delay of entry into a given market by competitors. As the expiration of the patent term is unpredictable, there is no economic rationale for a rival to plan a market entry. Then there are concerns with (1) a competitive market environment (Art. 170, IV, Brazilian Constitution), and (2) the patent holder's market power (Art. 173, 4th paragraph, Brazilian Constitution) which should be considered. Weak competitive pressure may trigger non-competitive prices, which in turn may result in harm to consumers (Art. 170, V, Brazilian Constitution). When it comes to medicines, the risks to fundamental health rights (Arts. 6 and 196 Brazilian Constitution), especially in a pandemic, are clear. ${ }^{22}$

Third, the term extension based on Art. 40, sole paragraph, IPA, caters to the individual interest of the patent holder, to the detriment of society. Innovative activities can be encouraged based on the standard exclusivity of Art. 40, caput, IPA, as most countries do, without the indeterminate duration provided by the sole paragraph. Exclusivity - an exception in a Constitution that boasts free competition as a principle - is the price to be paid in order to allegedly foster innovation. ${ }^{23}$ Patent protection allows that technology is known after publication of the application filing, but also enables that technology is used after a given period. Herein lies its social function, ${ }^{24}$ which is restricted by the lack of term limitation provided by Art. 40, sole paragraph.

\footnotetext{
${ }^{20}$ In 2018, the STJ considered that "from the application publication date (and not just from the patent grant) the holder already has legal protection to prevent the use, by third parties, of the product or process to which refers the application". Superior Court of Justice. Special Appeal No. 1,721,711-RJ. 3rd Chamber. Rap. Min. Nancy Andrighi. Date of judgment: 20 April 2018.

21 For the classic analysis of static versus dynamic competition, see Joseph A. Schumpeter "Capitalism, socialism and democracy". 5th edn. London and New York: Routledge, 1976. pp. 81-86. For a summary of the concept, see Mário André Machado Cabral "Concorrência dinâmica" In: José Francisco Siqueira Neto and Daniel Francisco Nagao Menezes (eds.). Dicionário de Inovação Tecnológica. Belo Horizonte: Arraes, 2020. pp. 77-78.

22 See Vitor Henrique Pinto Ido "The role of courts in implementing TRIPS flexibilities: Brazil Supreme Court rules automatic patent term extensions unconstitutional". South Centre Policy Brief, No. 94, June, 2021. pp. 3-5. Available at: https://www.southcentre.int/policy-brief-94-june-2021/.

23 The controversy on the role of intellectual property rights in fostering innovation is not new. Prominent scholars argue that this is not necessarily true. See e.g. George Stiglitz "Economic foundations of intellectual property rights". Duke Law Journal, vol. 57, 2008. pp. 1693-1724; Mariana Mazzucato "The value of everything: Making and taking in the global economy". 2nd edn. Penguin, 2019. pp. 202-228.

24 See Denis Borges Barbosa "Uma introdução à propriedade intelectual”. p. 413. Available at: https:// www.dbba.com.br/wp-content/uploads/propriedade13.pdf.
} 


\section{Final Remarks}

Some private attorneys and consultants have argued that, once the extension rule was in effect for 25 years (after the IPA entered into force in 1996), the unconstitutionality ruling would not be based on legal certainty and could result in negative economic impacts, especially in terms of an alleged decrease in investment incentives to innovation. ${ }^{25}$

However, at least two aspects should be highlighted. First, what brings about legal uncertainty in society is an undue and unconstitutional rule granting excessive exclusivity. Article 40, sole paragraph, IPA, is not a consequence of an international law commitment undertaken by Brazil. The regular terms provided by Art. 40, caput, are sufficient to put Brazil on track to comply with the TRIPS Agreement. The role of a Supreme Court is to independently analyze the rules under the Constitution. And the STF did so in this case.

Second, the STF has shown concerns for legal certainty as it has modulated the effects of the decision. A different legal framework for an industry with specificities (pharmaceutical, for instance) is justified in order to protect legitimate values, such as public health, particularly in the context of a pandemic.

Despite a 25-year delay, the STF's decision is correct in ruling Art. 40, sole paragraph, IPA, unconstitutional. Better late than never.

Acknowledgments I would like to thank Heloisa Santos, Maria Luiza Marques, Mariana Rodrigues and Pedro H. Batista for reading and discussing the text. Any errors are my own.

\footnotetext{
25 See e.g. Luciano Beneti Timm and Thomas Conti "Law and Economic do parágrafo único do art. 40 da Lei de Propriedade Intelectual". Jota, 27 October 2020. Available at: https://www.jota.info/opiniao-eanalise/colunas/coluna-da-abde/law-and-economics-do-par-un-do-art-40-da-lei-de-propriedade-

intelectual-27102020; Carlos Ari Sundfeld "O Supremo deve manter a extensão do prazo de validade das patentes no Brasil?" Sim. Folha de S. Paulo, 19 March 2021. Available at: https://www1.folha.uol.com. br/opiniao/2021/03/o-supremo-deve-manter-a-extensao-do-prazo-de-validade-das-patentes-no-brasil-sim. shtml; Floriano de Azevedo Marques Neto and Humberto Gomes Ferraz "Supremo acertou os sintomas, mas errou o remédio". Folha de S. Paulo, 8 June 2021. Available at: https:/www1.folha.uol.com.br/ opiniao/2021/06/supremo-acertou-os-sintomas-mas-errou-o-remedio.shtml; Rodrigo de Bittencourt Mudrovitsch, Alonso Freire and Victor Santos Rufino "Inovação, concorrência e segurança jurídica em risco com a ADI 5529”. ConJur, 7 April 2021. Available at: https://www.conjur.com.br/2021-abr-07/ opiniao-inovacao-concorrencia-seguranca-juridica-risco; Clara Cerioni "Não é competência do STF debater escolha do legislador sobre vigência de patente". Jota, 13 October 2020. Available at: https:// www.jota.info/casa-jota/competencia-stf-vigencia-patentes-13102020 (Ellen Gracie, Floriano de Azevedo Marques Neto and Carlos Ari Sundfeld, stating that the STF should not rule the Sole Paragraph unconstitutional and emphasizing allegedly negative economic consequences); Letícia Paiva "Extensãs do prazo de patentes industriais fere princípio constitucional?" Jota, 31 March 2021. Available at: https:// www.jota.info/casa-jota/extensao-do-prazo-de-patentes-industriais-fere-principio-constitucional31032021 (Floriano de Azevedo Marques Neto highlighting that the decision may cause a decrease in incentives to innovation investment and affirming that term extension rule "has been working for 25 years"; Licks. "Mudança na Lei de Patentes ameaça economia". Valor, 1 April 2021. Available at: https://valoz.globo.com/patrocinado/licks/noticia/2021/04/01/mudanca-na-lei-de-patentes-ameacaeconomia.ghtml.
} 
Publisher's Note Springer Nature remains neutral with regard to jurisdictional claims in published maps and institutional affiliations. 